\title{
FAMILY INSTITUTE: OBJECT AND EVOLUTION
}

\author{
(C)Abdikarimova S., Khwarazm Mamun Academy, Khiva, Uzbekistan, maqsuda_71@mail.ru
}

\section{СЕМЕЙНЫЙ ИНСТИТУТ: ОБЪЕКТ И ЭВОЛЮЦИЯ}

\author{
(C)Абдикаримова С. С., Хорезмская академия Мамуна, \\ 2. Хива, Узбекистан, maqsuda_71@mail.ru
}

Abstract. This article discusses the socio-philosophical, ethnological views of the institution of the family and their evolution as well as the issues that have so far been neglected.

Аннотащия. В статье рассматриваются социально-философские, этнологические вопросы формирования и эволюции института семьи, обсуждаются его некоторые методические вопросы. Показаны социальные отношения, связанные с цивилизацией Китая, Индии и Египта, типы культурных хозяйств, а также семейные отношения, роль родителей в воспитании детей.

Keywords: family, monogamy, polygamy, men's, women's, cultural traditions, myths, society, civilization, development.

Ключевые слова: семья, моногамия, полигамия, мужчины и женщины, культурные традиции, мифы, общество, цивилизация, развитие.

Numerous studies have been conducted on socio-historical, legal and sociodemographic development of the institution of the family yet, his analysis of ethnological ethnocentrisms has not yet been made. True, such analytical materials are found in all researches, but they are not summarized and analyzed in the context of a particular scientific, philosophical concept [1].

Men and women, sexual, moral, and property relationships play the main role in the formation of the family. These relations are formed in a certain cultural - ethnic and social environment. From this point of view, the formation of the family as an institution is an evolution of this relationship. Ethnological features become national traditions, local or regional, ethnicity attributes as an indispensable attribute of historical development.

Researchers have a certain meaning in their study of the institution of the family institution from the primitive moment. Mythological, animistic and totemistic views and views of that era played an important role in the subsequent development of the ethnos. If we recall that these imaginations and views continued until the emergence of Homo sapiens hundreds of millions of years, we are correctly aware of their importance. Therefore, myths and mythological concepts have become the attribute of human life, the culture it has created. Even ethnographers point out that the look, sight, and mood of a person have ethnological criteria [2, p. 75]. It is therefore natural that ethno-specific features exist in intercultural and interpersonal relations in the family. 
Intercultural relationships have emerged before intercourse. Sexual relations existed in the era of intercultural communication, and in the era when one did not recognize human self as a conscious being. Experts say that $96 \%$ of the human body is distinct from animals [3, p. 16].

Folk fairy tales and myths do not describe half-human beings, but half-human beings, and the first people are self-closely associated with the animal world. For example, the image of Alvasti in the mythology of the Turkic peoples is called the 'yellow girl' in the Zarafshan Valley. Alvasti could have become an animal or other lifeless objects at any time. The Kazan Tatars believed it to be a goat, a straw kit, a tree, and the Kazakhs a horse's hooves. Often it is described as a one-eyed creature, which can establish sexual relations with a man [4, p. 18-19]. This primitive, animalistic trait will later be worshipped by the ethnos.

According to the family thinkers, all the scientific, philosophical and ethnological views of the family are the two types of family, the union of men and women, and their joint economic management. Hence, the core of the family structure is men and women, and their economic relationships. This axiom does not wake up. However, when you look at the genesis of the family, there are many questions. How did a man and a woman realize the need to live together, to cooperate in the first and primitive phase of human society? How true is the vitality of Darwinism in this regard, why it rejects theological considerations? What can be attributed to the fact that etnoanstan has been preserving for many centuries in the formation of the institution of the family? Did family ethno-cults be influenced by ethnic groups, or were they influenced by other factors? What are these factors, their role in the transformation of ethno-religion? The answers to these questions require broad ethnological, ethnographic, historical, cultural and sociological research. At the same time, we are bound to address the historical and cultural heritage that has left a significant mark on the development of the personality society and the fundamental philosophical doctrine.

It is widely accepted that the first stages of the formation of human society are connected with the Chinese civilization, Indian civilization, and the civilization of the Egyptians during the IV-III millennium BC. The social relationships formed in these civilizations, cultural-economic types, and family problems can be clarified.

According to historical sources, in the third millennium BC, ancient Chinese had bamboo and wooden inscriptions and inscriptions. One of such writings is that she misses the shocks in her collections, in her collections, to return to her home and family circle. (5.154). So, in the third millennium BC, ancient Chinese had the concept of 'home', 'family', which they regarded as realities. The house is a home for them, a place where their dearest neighbours live, their neighbours, their borders, and their home and family. Unfortunately, historical sources do not tell us how these emotions originated. Interestingly, the ancient Chinese considered themselves to belong to this or that 'home', so they called their prime name 'home'. For instance, the House of Shan House, the House of Chjou, and the House of the Sower meant dynasties and princes of rulers. Shi (chief of the Home-affiliated staff, calligrapher) was entrusted with the work of the prince, the ruler's family, especially the management and the relationship [5, p. 157].

Through these texts, we find that the ancient Greeks' desire to live in a family was strong, and their perception of the homeland was related to the 'home', 'family', and even to Prince, government, and political government. In ancient China, the 'ritual codex' also contained these concepts, that is, the home, family, and homeland, the concept of the state, and the contradiction or differentiation. Communist lifestyle and communist ideas that are typical for the people of the Orient. This tradition is influenced by the formation of Confucianism in ancient China and its functioning as a state ideology. The concept of 'peacemakers' in the political, philosophical and moral heritage of Confucius (VI-V centuries BC) includes the Triumph of the Heavenly Father, Adam. 'Alijanov er', that is, a ruler, a family head, a fan of ritual tradition serves this triad. The 
harmony between the parts of the triad, the harmony, the observance of the requirements of the sky, is the responsibility of 'topjanov er'. He is the son of the Heavenly Son, the Son of the Heavenly Father, to follow His instructions to obey the demands of Heaven. According to Confucius, the whole state is a patriarchal family, symbolized by the word 'noble land'. 'When you leave the house', says Confucius, 'keep yourself as if you are the dearest guests. Treat people as if they were doing great images. Do not do anything that you do not want yourself to do. There will be no dissatisfaction both in the country and in the family' [6, p. 115-116].

Even when Confucius says 'sovereign ruler, servant, parent, son and son' [6, p. 164-165], he looks at the institution of the state and family and seeks to adhere to the principles of managing them with respect to the traditions left by goodness, justice and ancestors. Both the state and the family are governed by a certain tradition, and the violation of this tradition will lead to divergence, conflict, and disobedience to the servant ruler and son. Confucius offers many examples [7, p. 53113].

Ancient Chinese historian Ban Gu (AD 32-92) describes the peculiarities of the relationship between family, man and woman. According to the scholars, 'The way of a human being is (as a matter of course) a marriage. The relationship between men and women in the emotional and moral principles of Kishilar is not important. Relationships between men and women do not matter in the relationship between husband and wife. It is through these relationships that men and women, between and within and between the sky and the earth, maintain harmony, and inherit among generations, and ethical principles are ensured' [8, p. 52-53].

In the track, the question is why both men and women do not carry on their own initiative and are told to 'keep away from unlawful sexual relations and morality'. Marriage counselling comes from parents. The woman should be at least ten years younger than male and that she should be twenty-five and eighty-five [8, p. 53]. On both sides, the three-day lamp will not be turned off, the music will not be played, and the Ancestral Synagogue will not be reported until marriage for up to three months. At that time there is a 'generation change', bridegroom becomes a replacement for his father and prepares to become a bride. Within three months, young people learn each other, the bride adapts to the new home, the embryo expresses itself, and then reports to the ancestral synagogue about the change of marriage and generation.

The trick is to describe what male and female (s) are doing, how they should interconnect each other, and what to do in order to have a good marriage. The head of state, the ruler cannot marry twice, but at the same time tells the story of nine women, low-ranking officials, and ministers-two wives. The head of the household may remarry. The bride is not married to her husband, but serves as a mother and mother, according to the idea of the bridegroom, husband, and mother-in-law. 'The woman marries another family (TsZya) to marry her own family' [8, p. 59]. A man who is over sixty 'closures his wife's door', that is, to stop sexually abusing his body. As these traditions and traditions have been polygamy with monogamy in ancient China, it is evidenced that the institution of the family was organized according to specific social order, especially in the traditions. The tradition was a mandatory attribute of the institution of the family, and intergenerational relations were also within these traditions. Confessions and traditions that all social, political, and family relationships have established (including honoring the ancestry, obedience to the order they have created, the great older man, the ruler, the 'honorable husband' and the heavenly glory, the entrance into the marriage with the permission of the parents, monogamy, polygamy for officials, even marriage to his wife's sister and so on). "In the eighteenth and twelfth centuries BC, China had been marital relations. But it was later banned. Relationships are a system of non-consensual bride-grooming, which is a family name so that the seeds are unaware of their union. The Chinese family is based on the principle of 'one wife'. In family relationships, it was 
essential for a woman to be loyal to the husband and subject to her unconditional submission. The earth could have had 'secondary' wives (if not his wife) depending on their social status. Traditional Chinese law does not stipulate serious restrictions on marriage. 'Breach of husbands and wives', insults and injuries have become the basis for the marriage to be abolished. The wife has the right to cancel marriage if she does not 'justify the faith', that is, to obey a mother or father, to be incommensurable, with mild nature, envy, sickness, sickness, or family property" [9, p. 16-17].

In Indian civilization, there are many different contradictory views on the formation and interpretation of the institution of the family [10, p. 121]. From a social philosophical and ethnological point of view, they represent the heritage of the Indian people, their historical and cultural life, the relationships with women, and the future generations, especially spiritual advancement issues. Indian people have not denied the institution of the institution, although Buddhas (VI-V centuries BC) and Buddhism have negative thoughts [11, p. 3]. Buddha himself teaches, 'Love people as they love their mothers' [11, p. 21].

Epic of Mahabharata and Rigveda Sufficiently finds insight into the family and family relationships in ancient India. For example, Draupadi, the Hero, was married to the brothers, and at that time he pointed to the polygamy. This archaic marriage is linked to the preservation of family values, and the heroic battle against the heroes' enemies is related to the protection of the family honour [12, p. 7-9].

Rigveda also mentions family values, their divine attributes, and a prominent role of a woman in promoting life and marriage [13, p. 41-54].

In Arthashastra (III century), the idea of the royal family, the relationships with the Haran, the king's wife and their children were interpreted. Management of the family is a policy of the state, and its subjects can harm the king, so it is the duty of the special services to protect them from their negative influences and actions. [14, p. 46-48].

Malanaga Vatsyayan's Kamasutra plays an important role in the socio-philosophical and ethnological heritage of the Indian people. First of all, we must say that the erroneous idea of eroticism is widespread. Kamasutra encourages young people to love each other. No matter how greatly wealthy (property, property), especially in a society founded on property, cannot stop the love of those who love it. Yes, wealth, wealth, position, position, magnificence in the community, promise and desires. The development of Indian art is a result of the wealth of such wealthy individuals. But the covenant of lovers can overcome the barriers that make up the mind. 'Parents', suggests the author, "it is better to choose a poor woman who is more healer but happier with family if she wants to give her a boy who does not love her, or a rich man or a few wives. There are few wives, independent of wealth, and poor free. Boy's wives can have all the comforts but cannot be happier. But a few men are really rarely loved by one of them, so their wives look for other men. He cannot be a good landlord, lowly, weak, lonely traveler, gambling, or abandon his wife. Let the couple choose a couple to agree with. This place is best because it is a favorite place" [14, p. 207].

It is known from this leaf that the monogamy had polygamy in the Indians, many traditions followed, and it is common to give younger kisses to wealthy, wealthy men. M. Watsyaya thinks of monogamy as the foundation of the family, in the love of the young. He is the source of the love of the two sexes, enjoying the beauty and pleasure of their surroundings, and of loving each other. "The sensual aesthetic beauty, charm and pleasure of the Indian men and women, who viewed it as one of the decisive factors in maintaining a stable, sustainable, preserving tradition and strengthening the family life. For this reason, studies on zoology and gender psychology suggest that the distance between the rocks that are characterized by ezophilic psychophysiology is not always the same, which implies that men and women do not interfere with each other. Focusing on 
the subject negatively affects the hostility and intensifies the relationship between the sexes" $[15, \mathrm{p}$. 203].

It should be remembered that Kamasutra is genuinely supportive of marriage, taking into account the tastes and intrigues of each other [16, p. 24-29]. The erotic scenes that have become part of the Hinduism are not the propagation of non-divine, phoney, but the persistence of the two sexes, both spiritually and exemplary, from the body [16, p. 267-269]. There are plagiarisms in the Herculean, Hindu, and Chinese erotologies, but it is impossible to deny that the relationship between the two sexes is based on a stable family.

At the early stages of human society development, studies suggest that polygamy, polyglinia, gonorrhea or gonorrhea, and endogamia are commonplace. However, during the formation of the family as a monogamy institute, these primitive habits are forbidden, disrupted by social life, such as taboos, multiple marriages, polygamy, homosexuality, marriage to relatives, harmful and nonformalities. This requirement in social life varies widely in different cultures, and some ethnological and ethnographic observations confirm that they have a chance to meet. For example, in the early stages of the marriage, a group of two tribal tribes, almost all ethnic groups, who had been examined by L. Morgan [17, p. 156-162], were examined by the family and began to distinguish between the barbaric, humane, tribal families and people in them, the concept of the family and its composition has also changed. Therefore, the personality assessment was reflected in the family trick, the differentiation of socio-economic relations, and the processes of labor led to the discrimination of male and female, husband and wife. At the same time, it is important to note that the family maintains its core in the process of family juvenile and that the core is built into two sex units, and the family consists of their allies. In this case, he denied the incubators, the rumors of the revolutions, as foreign, foreign. Unfortunately, society and social relationships have chosen the path of evolution. The current order has changed the core of these procedures forcefully. Hence, if the family does not perceive the outside world, it will try to keep its core in any contradictory situation.

Polygamy, or companionship, endogamy in the early stages of the human society are transformed by centuries and transformation of humanistic freedoms in the society, with new traditions promoting family affairs. The idea of sharing the family as a union of two sexes has not changed, but the fact that these subjects are of different ethnicity, ethnicity, and the extent of their belonging is the victory of universal civilization.

Managing the institution of the family with the advancement of men's roles and the advent of traditions are patriarchal. In the Hammorapi Law, articles 117-212 deal with family, family relationships, and relationships between husband and wife. They are forbidden to have sex with their own mother, sister, and daughter [18, p. 46-52]. In them, the head of a family is a male, which is reflected in articles in the patriarchal approach law. It is stated that man has a wife, has a slavegirl, a slave-girl, and can divorce her at any time. Endogenous relationships are forbidden because of changes in the family, but many males are not forbidden to wealthy men. Thus, it is common for a man to live with two, three or more wives. Now, the interpretation of the family and its circle are characterized by a man, and the family is adjusted to the assessment of the potential for the potential. But in ordinary people, the family is perceived as monogamy and its relationships are organized in accordance with the principles of gender equality. This controversy points to the fact that some researchers believe that twenty-century history is a time when past traditions and traditions have faded. Therefore, in our opinion, it is necessary to look at the family analysis from the point of view of the above contradictions; otherwise there will be a straight-line approach. We approach the evolution and development of the institution of the family associated with the development of social relations and the uneven development of the society. 


\section{References:}

1. Haviland, L. S. (1887). A woman's life-work: labors and experiences of Laura S. Haviland. CV Waite \& Company.

2. Toporov, V. (1995). Svyatost' i svyatye v russkoi dukhovnoi kul'ture. Tom I. Pervyi vek khristianstva na Rusi.

3. Piz, A., \& Piz, B. (2011). Kak zastavit' muzhchinu slushat', a zhenshchinu molchat'. Pochemu my takie raznye, no tak nuzhny drug drugu. Moscow, Eksmo, 349.

4. Valyanskaya, O. P. (1992). Zhenshchina v mifakh i legendakh. Entsiklopedicheskii slovar'. Moscow, 220.

5. Sedov, A. V. (2004). Istoriya drevnego Vostoka. Ot rannikh gosudarstvennykh obrazovanii do drevnikh imperii. Moscow, Vostochnaya literature, 894.

6. Perelomov, L. C. (1998). Konfutsii: Lun' yui. Moscow, Vostochnaya literature, 588.

7. Mysliteli drevnego i srednevekovogo Kitaya. (2005). Moscow, AST, 348.

8. Andreeva, I. S., \& Gulygina, A. V. (1991). Sem'ya, Kniga dlya chteniya. Kn. 1. Moscow, Politizdat, 346.

9. Buriev, O. \& Usmanov, M. (2012). Turkish family. Tashkent, Uzbekistan. 16-17.

10. Toporova, V. N. (1993). Dkhammapada. St. Petersburg, Chernyshev, 174.

11. Budda: Zhizn', Uchenie, Mysli, Izrecheniya, Aforizmy. (1998). Minsk, Sovremennoe slovo, 320.

12. Vasilkov, Ya. V., \& Neveleva, S. L. (1987). Makhabkharata. Kniga tret'ya, Aran'yakaparva (Lesnaya). Moscow, Nauka.

13. Rigveda. Mandaly I-IV. Moscow, 1989.

14. Kautilya. (1959). Artkhashastra ili nauka politiki. Moscow, Leningrad, Izdatel'stvo akademii nauk SSSR, 802.

15. Alimasov, V. (2007). Philosophy or thirsty of thought. Tashkent, Philosophy and law.

16. Mallanaga, V. (2016). Klassicheskaya kamasutra. Polnyi tekst legendarnogo traktata o lyubvi. Moscow, Eksmo. 224.

17. Semenov, Yu. I. (1974). Proisxojdenie braka i semi. Mascowa, Nauka, 156-162.

18. Arapov, A. (2016). Istoricheskie pamyatniki Uzbekistana. SMI-Aziya, 138

\section{Список литературыл:}

1. Haviland L. S. A womanэs life-work: labors and experiences of Laura S. Haviland. CV Waite \& Company, 1887.

2. Топоров В. Святость и святые в русской духовной культуре. Т. І. Первый век христианства на Руси. М., 1995. 875 с.

3. Пиз А., Пиз Б. Как заставить мужчину слушать, а женщину молчать. Почему мы такие разные, но так нужны друг другу. Москва, Эксмо, 2011. 349.

4. Валянская О. П. Женщина в мифах и легендах. Энциклопедический словарь. М., 1992. $220 \mathrm{c}$.

5. Седов А. В. История древнего Востока. От ранних государственных образований до древних империй. М.: Восточная литература, 2004. 894 с.

6. Переломов Л. С. Конфуций: Лунь юй. М.: Восточная литература, 1998. 588 с.

7. Мыслители древнего и средневекового Китая. М.: АСТ, 2005. 348 с.

8. Андреева И. С., Гулыгина А. В. Семья: Книга для чтения. Кн. 1. М.: Политиздат, $1991.346 \mathrm{c}$.

9. Buriev O. Usmanov M. Turkish family. Tashkent: Uzbekistan, 2012. C. 16-17. 
10. Топорова В. Н. Дхаммапада. СПб.: Чернышев, 1993. 174 с.

11. Будда. Жизнь: Учение: Мысли: Изречения: Афоризмы. Минск: Современное слово, $1998.320 \mathrm{c}$.

12. Васильков Я. В., Невелева С. Л. Махабхарата. Книга третья, Араньякапарва (Лесная). М.: Наука, 1987.

13. Ригведа. Мандалы I-IV. М., 1989.

14. Каутилья. Артхашастра или наука политики. М., Л.: Издательство академии наук CCCP, 1959. $802 \mathrm{c}$.

15. Alimasov V. Philosophy or thirsty of thought. Tashkent: Philosophy and law, 2007.

16. Малланага В. Классическая Камасутра. Полный текст легендарного трактата о любви. М.: Эксмо, 2016. 224 с.

17. Семенов Ю. И. Происхождение брака и семьи. М.: Мысль, 1974. 309 с.

18. Арапов А. Исторические памятники Узбекистана. СМИ-Азия, 2016. 138 с.

Работа поступила

в редакцию 20.04.2019 2.
Принята к публикаиии 25.04.2019 2.

Ссылка для циитирования:

Abdikarimova S. Family Institute: Object and Evolution // Бюллетень науки и практики. 2019. T. 5. №5. C. 460-466. https://doi.org/10.33619/2414-2948/42/68.

Cite as (APA):

Abdikarimova, S. (2019). Family Institute: Object and Evolution. Bulletin of Science and Practice, 5(5), 460-466. https://doi.org/10.33619/2414-2948/42/68. 